\title{
Psychological Problems of Athletes in Undergoing Independent Training Programs During the Pandemic Covid-19
}

\author{
Jatmiko Tutur ${ }^{1}$, Suryanto $^{2}$, Priambodo Anung ${ }^{3}$ \\ ${ }_{1}^{1}$ Postgraduate Doctoral Sport Science Program, Universitas Negeri Surabaya, Indonesia \\ ${ }^{2}$ Faculty of Psychology, Universitas Airlangga, Indonesia \\ ${ }^{3}$ Faculty of Sports Science, Universitas Negeri Surabaya, Indonesia \\ Email: said.20007@mhs.unesa.ac.id, suryanto@psikologi.unair.ac.id, anungpriambodo@unesa.ac.id
}

\begin{abstract}
The global pandemic caused by the Covid-19 virus reduces human activities in various aspects of life, including sporting events. Restrictions on activities on a large scale make sporting events that have the potential to gather large numbers of people prohibited from being held to prevent the transmission and spread of this virus. In addition to sporting events, preparatory exercises for sporting events must also be carried out independently in their respective homes. The implementation of independent training in the long term with supervision through online media has an influence on athletes in physical, technical, tactical and psychological performance. The purposes of this study are (1) to describe the psychological problems of athletes carrying out independent training programs during the covid-19 pandemic, (2) to explore the causes of psychological problems, (3) to explore the strategies chosen by athletes in overcoming psychological problems. The method used in this research is descriptive qualitative with a case study approach through in-depth closed interviews with sports athletes who run an independent training program during covid 19. Data analysis was carried out using the step of grouping problematic data that occurred and presented in the form of percentages and discussion The results of this study show Independent exercise programs at home have a psychological impact on athletes in the form of anxiety, boredom, stress, and obsession. Suggestions from the results of this study should be exercise in quarantine involving athletes and coaches in one camp equipped with training facilities and a recreational situation.
\end{abstract}

Keywords: psychological problem; athlete; exercise programs independent

\section{Introduction}

Global public health emergency status (Global Public Health Emergency) since declared by the World Health Organization (WHO), in January 2020. The state of public health emergency can affect the health, safety, and welfare individual (e.g., discomfort, confusion, emotional isolation, and stigma) and community (because of economic loss, job and school closures, inadequate response to medical resources, and inadequate distribution of needs) (Betty Pfefferbaum, 2020). Taking into account the recommendations of health authorities, several national and international athletic events, including the 2020 Olympics, have been postponed or canceled in an effort to limit the spread of the virus by attending to crowds. These cancellations and the widespread mandate for social distancing are having a negative impact on athletes who are unable to continue training routines (World Health Organization, 2020). Countless positive COVID-19 tests in competitive athletes at the global level and in the league premier have shown that none is safe (Corsini, Bisciotti, et al, 2020). 
Cancellations and postponements of activities that involve mass gatherings with social restrictions, music concerts and sporting events around the world aim to break the chain of virus spread. Including the athlete training center program was stopped to prevent transmission. Atlet and official repatriated each athlete to the area prior to implementation of large-scale social restrictions (PSBB) by the government in Jakarta 10-23 april 2020, 15 to 28 April 2020 in West Java and East Java 28-11 May 2020. Large-scale Social Restrictions (PSBB) during the outbreak certainly affect the psychological. During an infectious disease outbreak, psychological reactions in the population play an important role in shaping the emotional distress and social disruption of the spread of the disease during and after the outbreak (Cullen, et al. 2020). Psychological reactions to the pandemic include maladaptive behaviors, emotional distress and defensive responses (Taylor S, 2019).

According to Ningrum (2020) since the outbreak of the corona virus that was recorded starting at the end of 2019 in China, precisely the city of Wuhan, then later this virus became global and infected almost all countries in the world including Indonesia. The Covid19 pandemic caused everyone to behave beyond normal limits as usual. One of the behaviors that can change is deciding the decision to choose a college (Sihombing, 2020). The Covid-19 pandemic has also had an impact on athletes. The lifestyle of elite athletes is influenced by economic and social factors of society, family circumstances, individual aspirations and professional mindset (discipline, athlete behavior, and professional relationships). Therefore, each event that changes their lifestyle can have a different psychological effect. The spread of the Covid-19 disease and the lack of effective treatment have led to the cancellation of most sporting activities in the world, resulting in the quarantine of elite athletes. Since quarantine at home has disrupted regular training and competitive programs (Shahabi Kaseb, 2020).

Even though the athletes have been sent back to their respective homes, they are required to train to maintain their respective fitness so as not to experience a significant decrease in performance. So that athletes carry out independent training programs so that performance is maintained and can prevent contracting the covid-19 virus.

\section{Research Methods}

Method used in this research is descriptive qualitative with a case study approach through in-depth closed interviews with sports athletes who run an independent training program during covid 19. Data analysis was carried out using the step of grouping problematic data that occurred and presented in the form of percentages.

Qualitative descriptive research methods are used to describe and provide an overview of the object being studied, including describing the phenomena in the implementation of the research including the presentation of questionnaire data in the form of words to the research results. Data were taken from 33 respondents from several categories of sports, games, concentration and martial arts.

This study uses a questionnaire "Psychological problems of athletes in undergoing independent training programs during the covid-19 pandemic" which contains questions about the psychological experiences of athletes in undergoing independent training programs during the pandemic, implementation of training programs, facilities and infrastructure and training monitoring systems due to the impact of the COVID-19 pandemic. 19. There are 3 choices answer; Yes, No, and reasons or opinions. In data collection there are 7 indicators to determine the psychological impact of independent training during the pandemic, namely; 1 ) 
independent training program, 2) facilities and infrastructure, 3) psychological problems, 4) psychological impact, 5) exercise program, 6) team sports, 7) exercise control.

\section{Results and Discussion}

\subsection{Results}

The results of the independent exercise program indicator research, on the aspects of the implementation of the independent exercise program and the effectiveness of weight training in the independent exercise program 51.5\% stated that it had no impact and was not effective because the exercise situation was not monitored optimally, while $48.5 \%$ stated that it had an impact and effective, because it is free to adjust the pattern of rest and increase skills individually. In the aspect of program implementation, $78.7 \%$ stated that they were unable to implement the program, due to inadequate facilities and equipment and $21.3 \%$ said they were able to implement the program because they had the equipment. In the aspect of maximum exercise implementation, $60.6 \%$ stated that they could not carry out optimally, because they needed practicing partners and coaches as supervision and correction, but $39.4 \%$ were able to carry out optimally because they already understood the training program from the trainer.

In the indicators of training facilities and infrastructure, the aspect of using training facilities and infrastructure $81.8 \%$ said it was difficult because it needed equipment, equipment operators and trainers to improve performance and 18.2\% said no because the sport was individual. While the aspects of the exercise program according to the facilities and infrastructure at home $84.8 \%$ stated that it was appropriate but still could not support optimal performance improvement and $15.2 \%$ stated that it was not in accordance with the conditions at home and did not run according to the exercise program, but tried to modify the exercise with makeshift tools.

Judging from the indicators of the psychological impact of the implementation of independent training, 69.6\% stated that it had an impact on the psychology of athletes, and $30.4 \%$ stated that it had no impact psychological, this was influenced by the experience of the athletes themselves, where young athletes who still needed supervision and guidance from coaches did not get it directly. This affects the athletes' self-confidence, of which only $33.3 \%$ believe independent training programs can optimize their performance while $66.7 \%$ believe that independent training programs improve their performance. In the aspect of selfconfidence, $54.5 \%$ of athletes felt that their performance had decreased compared to before and $45.5 \%$ said they had not experienced a decline. This is due to the difficulty of practicing alone at home by $51.6 \%$, respondents because they need partners and adequate tools and $48.4 \%$ stated that they have no difficulty practicing at home. In the togetherness aspect of training, $100 \%$ of athletes stated that they wanted to train with coaches and fellow athletes in the same team because they needed supervision, practice matches and competitors to improve performance.

Regarding the effect of independent training on finance, $51.6 \%$ stated that it had an effect, because they had to prepare and buy their equipment own to run an independent training program and $48.4 \%$ of athletes said it had no effect because they already had equipment. Although they stated that they were financially influential, athletes did not object to the policy of reducing the training center budget for the prevention of COVID-19, $81.8 \%$ said they did not mind that the pandemic would end soon and return to normal, and $18.2 \%$ objected because there were still many needs that must be met. . In the implementation of the online independent training program, $24.2 \%$ of athletes stated that it was optimal because they carried out training as usual, only with a different monitoring model and $75.8 \%$ stated that it 
was not optimal, because through online the trainer's point of view in supervision and signal constraints made training less effective and efficient. .

While undergoing the independent exercise program, athletes still carry out health protocols, namely mandatory hand washing, $84.9 \%$ athletes run because the virus can be anywhere and is contagious, and $15.1 \%$ do not run because they are at home and do not have much contact withpeople other outside the home. However, $54.6 \%$ of athletes feel confident and are not afraid of crowds, because they are physically and stronger and healthier than ordinary people and $45.4 \%$ of athletes are afraid of crowds because the virus can infect anyone. Although they are not afraid of crowds, $63.6 \%$ of athletes are afraid of being infected by covid-19, because one of the effects of illness is on the lungs which can reduce the endurance performance of athletes and $36.4 \%$ are not afraid of being infected because they feel have better immunity than ordinary people.

Therefore, they believe that PON XX 2021 will be held, it is proven that $93.9 \%$ of athletes say so because the pandemic will end soon and $6.1 \%$ are still not sure that PON can be held because it is not clear when the pandemic will end and ban events and crowds. If PON is held, they are 100\% sure to be the champion, considering that they have been practicing for a long time and competitors have experienced the same difficulty practicing during the pandemic.

Running an independent training program certainly has difficulties its own, because there is no direct supervision from the trainer. However, $93.9 \%$ of athletes stated that they were able to understand the training program from the coach even though it was carried out independently, but it was not optimal considering that online supervision and correction was different from the real situation, while $6.1 \%$ were really unable to understand the independent training program. Even though the training program is according to conditions at home according to the opinion of $84.8 \%$ of athletes, and $15.2 \%$ stated that the training program is not appropriate to the conditions at home, athletes still have difficulty running without direct control from the coach, although $90.9 \%$ stated that the coach still provides a weight training program for maintain physical quality, while $9.1 \%$ is not given due to equipment limitations, athletes still feel many shortcomings in carrying out independent training programs. The mentality of being a disciplined athlete is still firmly held by athletes, 100\% of athletes do not experience disciplinary problems in carrying out independent training programs, because it has become a habit and a commitment to achieve achievements, even though the atmosphere is much different from before in terms of place, facilities, equipment and without colleagues practice with supervision carried out by online trainers.

The supervision carried out online was considered ine ffective by athletes, as seen from $81.8 \%$ stating that online supervision was not effective and $28.2 \%$ only said it was effective. This is influenced by signals, visibility, the point of view of the coach in supervising the course of the exercise, so that the athlete feels that there is not much significant progress from the results of the exercise carried out. In addition, $90.9 \%$ of athletes said coaches often compared their abilities and training results before and after the pandemic, where they were much better at the time before the pandemic and 9.1\% said they had never been compared. From this condition, $81.8 \%$ of athletes stated that they wanted to provide input regarding control by coaches in training related to mastering online training technology so that the results were more effective and efficient and $18.2 \%$ considered coaches to be competent and successful in independent training programs with online supervision. 
The independent training program has its own obstacles for team sports, especially inexperienced young athletes, the results of the data obtained are $72.7 \%$ Athletes also have difficulty in independent training programs because they do not have equipment and training partners, so they feel they lose chemistry between players in communication and teamwork, $26.3 \%$ felt they had no difficulties in communication and teamwork. However, $90.9 \%$ of athletes experienced a decline in team performance and only $9.1 \%$ stated that the team's performance did not decrease.

\subsection{Discussion}

Implementation of an independent training program during the COVID-19 pandemic has had a psychological impact on athletes. Anxiety is one of the psychological impacts experienced by athletes, where athletes feel that their performance during training does not increase and tends to decrease, even though they have the confidence to win because they also think that their competitors have the same training problems. The need to train with coaches and fellow athletes is a source of anxiety for athletes. They feel they do not get correction from the coach and practice matches to see changes in training results. During the self-training program, the athlete does self-quarantine at home, of course this has an impact on the athlete's psychology, namely boredom and stress. Quarantining for several months and meeting the same people at home has the potential to cause boredom and stress. Practicing every day alone, monitoring online methods, constrained signals and in adequate equipment also make athletes also stress about performance which tends to decline. And the reduction of training facilities for the prevention of COVID-19 is also one of the triggers for athletes' stress from a financial perspective.

\section{Conclusion}

Fear and obsession become the psychological impact of athletes in independent training programs, this is due to fear of not holding PON by the government because of this pandemic, because it has become the hope of athletes to compete after so long practicing and of course bonuses as prizes for success in PON. Of course it will be a disappointment for athletes if it is not implemented. In addition, with independent training, athletes feel that their condition is not perfect to compete inevents PON. In addition athletes are afraid of the crowd and always wash hands to avoid contracting the virus even though they have no fear of contracting the virus because they feel healthy and trained.

\section{References}

Atherstone, C., Peterson, ML, Malone, M., Honein, MA, MacNeil, A., O'Neal, CS, \& Barrios, LC (2021). Time from Start of Quarantine to SARS-CoV-2 Positive Test Among Quarantined College and University Athletes- 17 States, June-October 2020. Morbidity and Mortality Weekly Report, 70(1), 7.

Athletes in Home Quarantine Quaid-19: Phenomenological Study Sport Psychology Studies Volume 9, No 32, 2020, Page 161-184.

Betty Pfefferbaum, MD, JD, and Carol S. North, MD, MPE (2020) Mental Health and the Covid-19 Pandemic. The New England Journal of Medicine. DOI: 10.1056/NEJMp2008017.

Corsini, A., Bisciotti, GN, Eirale, C., \& Volpi, P. (2020). Football cannot restart soon during the COVID-19 emergency! A critical perspective from the Italian experience and a call for action.

Corsini, A., Bisciotti, GN, Eirale, C., Volpi, P., 2020. Football cannot restart soon during the COVID-19 emergency! A critical perspective from the Italian experience and a call for 
action. BMJ Publishing Group Ltd and British Association of Sport and Exercise Medicine. https://doi.org/10.1136/bjsports 2020-102306.

Cullen, W., Gulati, G., \& Kelly, BD (2020). Mental health in the Covid 19 pandemic. QJM: An International Journal of Medicine, 113(5), 311-312.

Di Cagno, A., Buonsenso, A., Baralla, F., Grazioli, E., Di Martino, G., Lecce, E., \& Fiorilli, G. (2020). Psychological Impact of the Quarantine-Induced Stress during the Coronavirus (COVID-19) Outbreak among Italian Athletes. International Journal of Environmental Research and Public Health, 17(23), 8867.

Håkansson, A., Jönsson, C., \& Kenttä, G. (2020). Psychological distress and problem gambling in elite athletes during COVID-19 restrictions-A web survey in top leagues of three sports during the pandemics. International Journal of Environmental Research and Public Health, 17(18), 6693.

Jukic, Igor, et al. "Strategies and solutions for team sports athletes in isolation due to COVID19." (2020): 56.

Khan, S., \& Huremović, D. (2019). Psychology of the pandemics. In Psychiatry of Pandemics (pp. 37-44). Springer, Cham.

Makarowski, R., Piotrowski, A., Predoiu, R., Görner, K., Predoiu, A., Mitrache, G., ... \& Nikkhah Farkhani, Z. (2020). Stress and coping during the COVID-19 pandemic among martial arts athletes-a cross-cultural study. Archives of budo, 16, 161-171.

McGee, U., \& Sanders, E. (2020). Letter to the editor regarding the effect of isolation on athletes' mental health during the COVID-19 pandemics. The Physician and Sportsmedicine, 1-1.

Mehrsafar, AH, Gazerani, P., Zadeh, AM, \& Sánchez, JCJ (2020). Addressing potential impact of COVID-19 pandemic on physical and mental health of elite athletes. Brain, behavior, and immunity.

Morrey, Luke B., William O. Roberts, and Lora Wichser. "Exercise related mental health problems and solutions during the COVID-19 pandemic." Current sports medicine reports 19.6 (2020): 194.

MR Shahabi Kaseb1, ES Askari Tabar2, and K. Ayobzade3 Analysis of Psychological Experiences of Iranian Elite.

Ningrum, P.A., Hukom, A., and Adiwijaya, S. (2020). The Potential of Poverty in the City of Palangka Raya: Study SMIs Affected Pandemic Covid 19. Budapest International Research and Critics Institute-Journal (BIRCI-Journal) Vol 3 (3): 1626-1634.

Pfefferbaum, B., \& North, CS (2020). Mental health and the Covid-19 pandemics. New England Journal of Medicine, 383(6), 510-512.

Rasyid, MLSA, \& Kusnanik, NW (2021). Athlete's Training Motivation Badminton During a Pandemic Covid-19. Achievement Journal Sports, 4(4), 128-138.

Reardon, Claudia L., et al. "Mental health management of elite athletes during COVID-19: a narrative review and recommendations." British journal of sports medicine (2020).

Rossato, C., Sly, D., Cumming, S., \& Gorczynski, P. (2020). The psychological impact of Covid-19 on elite athletes. The Sport and Exercise Scientist (TSES), (65), 28-29.

Schinke, R., Papaioannou, A., Henriksen, K., Si, G., Zhang, L., \& Haberl, P. (2020). Sport psychology services to high performance athletes during COVID-19.

Shahabi Kaseb, M., Askari Tabar, ES, \& Ayobzade, K. (2020). Analysis of Psychological Experiences of Iranian Elite Athletes in Home Quarantine Quaid-19: Phenomenological Studies. Sport Psychology Studies, 9(32), 161-184.

Sihombing, E.H., and Nasib. (2020). The Decision of Choosing Course in the Era of Covid 19 through the Telemarketing Program, Personal Selling and College Image. Budapest International Research and Critics Institute-Journal (BIRCI-Journal) Vol 3 (4): 28432850 . 
Usher, K., Durkin, J., \& Bhullar, N. (2020). The COVID-19 pandemic and mental health impact. International Journal of Mental Health Nursing, 29(3), 315.

W. Cullen, G. Gulati2 and BD Kelly 3 (2020). Mental health in the COVID-19 pandemic. International Journal of Medicine, 2020, 311-312. doi:10.1093/qjmed/hcaa110.

Textbook:

Firdaus, K. (2021). Sports Psychology Theory and Applications: Kamal Firdaus. Kamal Firdaus.

Taylor S. 2019. The Psychology of Pandemics: Preparing for the Next Global Outbreak of Infectious Disease. Newcastle upon Tyne, Cambridge Scholars Publishing.

Thesis/Thesis/Dissertation:

Aryani, STS, \& Adhe, KR (2018). Parenting Parenting Survey with Motion Development Kindergarten A Children's Motor in Surabaya Center.PAUD Lotus, 7(2).

The Website of the World Health Organization, 2020 http://www.euro.who.int/en/health topics / healthemergencies / coronavi rus-covid 19/news/news/2020/3/mental health-andpsychological-resilience during-the-covid-19-pandemic. access date: 19-042021 